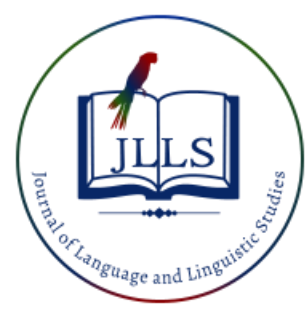

Available online at www.jlls.org

JOURNAL OF LANGUAGE AND LINGUISTIC STUDIES

ISSN: $1305-578 \mathrm{X}$

Journal of Language and Linguistic Studies, 16(3), 1443-1457; 2020

\title{
Codeswitching in group work in EFL classes
}

\author{
Elif Kemaloglu-Er a 1 (D), Hatice Özata ${ }^{\text {(iD }}$ \\ a Adana Alparslan Türkes Science and Technology University, Adana, Turkey
}

\section{APA Citation:}

Kemaloglu-Er, E., \& Özata, H. (2020). Codeswitching in group work in EFL classes. Journal of Language and Linguistic Studies, 16(3), 14431457.

Submission Date:31/05/2020

Acceptance Date:30/06/2020.

\begin{abstract}
Codeswitching is reported to be a common feature of group work in EFL classes, particularly those with learners sharing the same native language. On the other hand, there is little research on codeswitching in group work in EFL contexts. This study aims to investigate the reasons why codeswitching is employed in EFL group work interactions among learners who share the same native language. The data were collected via observations of group work processes and open-ended questionnaires given to the students and thematically analysed. According to the findings, codeswitching in group work served mainly four types of purposes: i) search for equivalence, ii) meaning clarification, iii) following task procedure and iv) emotional expression. The task type being a spontaneous speaking task or an outcome production task and the students' being in an on-record or off-record mode also affected the extent of codeswitching. Another finding was that the instructor's use of L1 in the classroom might derive students to switch codes. The students reported that they switched from English to their native language particularly due to their lack of proficiency and the fact that they found L1 communication a convenient way of expressing their concerns and emotions. Codeswitching was found to be a builder of solidarity and a means of achieving task targets as well as interactional fluency, implying that it can serve pedagogically useful purposes in group work in EFL classes.
\end{abstract}

(C) 2020 JLLS and the Authors - Published by JLLS.

Keywords: codeswitching; codeswitching in group work; codeswitching in EFL classes; group work; reasons for codeswitching

\section{Introduction}

Codeswitching can be defined as "a phenomenon of switching from one language to another in the same discourse" (Numan \& Carter, 2001, p.275). It is a widespread phenomenon which is especially observed in multilingual and multicultural communities. It can well be a part of the English classroom consisting of students with different native languages or sharing the same native language. In a foreign language classroom, the languages between which alternation takes place are the native language/s of

\footnotetext{
${ }^{1}$ Corresponding author. Tel.: +0-322-4550000

E-mail address: ekemalogluer@atu.edu.tr
} 
the students and the teacher, and the foreign language that students are expected to gain competence in, which is English in our case.

There are mainly three views about codeswitching and accordingly the use of L1 in the English classroom. On one hand, there is the approach maintaining that codeswitching and L1 must totally be avoided from the classroom context and thus L2 must be the only language used in the class. It is audiolingualism, oral and direct methods that support this perspective (Larsen-Freeman, 2000). According to this paradigm, depending extensively on L1 might lead to confusion about which language to use in the classroom, which might influence the quality and quantity of L2 input (Chaudron, 1988; Ellis, 1984; Prucha, 1983; Wong-Fillmore, 1985). One concern is that as a result of breakdowns in L2 exposure, the students cannot improve their communication skills as much as they would in an Englishonly situation and lose their motivation to learn and the ability to perform effective interactions (Bhatt, 1997; Brown, 2007; Chambers, 1991). As for another concern, codeswitching by either the learner or the teacher can increase the use of non-target forms leading to deviant linguistic patterns and this may pave the way for internalization and fossilization of these non-standard uses of language (Jingxia, 2010; Martin, 1999; Zhu, 2008).

On the other hand, there is the grammar-translation method where the use of L1 and translation highly govern language learning. It is alleged that L1 must be predominantly used to teach the equivalences of lexical items and grammar structures on a translation basis (Richards \& Rodgers, 2001). In between the two extremes, there is the approach which defines codeswitching as a supportive means that can be used limitedly, that is, only in suitable circumstances when it is necessary. However, one must also be aware of the limitations of it since it may have negative effects on the learners' production of L2. This view as a mid-point in between two extremes came to the fore of second language instruction after the emergence of the communicative language teaching approach (Atkinson, 1993; Harmer, 1983; Weschler, 1997) and turned into a stronger argument with the post-methods era (Kumaravadivelu, 2003a, 2003b), and recently the perspective is highly supported in ELF and Global Englishes pedagogy (Kemaloglu-Er \& Bayyurt, 2018, 2019a, 2019b; Galloway \& Rose, 2015, 2018).

The supporters of the paradigm that highlights the moderate use of codeswitching in L2 classrooms agree that codeswitching in the classroom helps save time and energy, minimizes confusion among learners and motivates them about learning the second language since the language is conceived to be easier to learn (Burenhult \& Flyman-Mattsson, 1999; Cook, 2016; Crystal, 1987; Greggio \& Gil, 2007; Levine, 2003; Sert, 2005). Codeswitching is also reported to provide continuity in speech and contribute to the fluency of communication and ease self-expression (Matila 2009; Rosario \& Maguddayao, 2019). Lastly, the existence and the necessity of codeswitching and its facilitating role in the second and foreign language classrooms is a common finding of a number of studies as it serves as a compensatory tool in the L2 classroom, reduces the stress level of the learners and encourages learning (Duff \& Polio, 1990; Lally, 2000; Lin, 2008; Macaro, 2009; Macaro \& Lee, 2013; Martin-Jones, 1995; Miles, 2004; Sampson, 2012; Sutherland, 2012; Turnbull, 2001; Üstünel \& Seedhouse, 2005; Xu, 2010; Vaezi \& Mirzaei, 2007; Zabrodskaja, 2007).

According to the post-methods perspective, it is suggested that L1-L2 connection is an indisputable fact of life and the use of L1 as a rich resource enables the teacher to make a connection between the home language and the target language and hence, ensures social relevance (Kumaravadivelu 2003a, 2003b; Stern, 1992). Besides, within the context of ELF-aware pedagogy, Kemaloglu-Er and Bayyurt (2018, 2019a, 2019b) indicate that L1 is a significant asset of a non-native speaker and allowing it in the English classroom is an egalitarian and humanistic way of implying the acknowledgement of nonnative speakers with their own features and varieties. Galloway and Rose (2018) similarly indicate that in Global Englishes language teaching, L1 is seen not as a hindrance and a source of interference, but 
as a resource to utilize in learning about the diversity of Englishes used by speakers of different native languages in pluristic ways.

In an English classroom, students' codeswitching can fulfil various functions. According to Eldridge (1996), students may codeswitch in order to use the native equivalent of a certain lexical item in target language, fill the stopgap with native language use during a conversation in the target language, repeat the L2 message in native language for clarification purposes and avoid misunderstandings to transfer the intended meaning. Matila (2009) states that students can codeswitch for several purposes like easier self-expression, not knowing the right word, effects of people around, habitual causes, establishing fluency and feeling comfortable. Several scholars also mention the humanistic functions of codeswitching behavior in English lessons. According to Cook (2016), codeswitching is a natural response in a bilingual situation and gives the learners pressurized by the deficiency of not knowing the right vocabulary and the fear of making mistakes a chance to express themselves. Weschler (1997) argues that L1 in the L2 classroom is not a scapegoat that always causes a problem but a kind of compensatory tool that L2 learners can make use of to learn the target language. To illustrate, codeswitching helps students build their vocabulary, comprehend complex matters, understand classroom activities and raise learners' awareness about cross-cultural differences (Bateman, 2008; Qing, 2010; Yang, 2004). Switching to learners' code in the L2 classroom may give the learners a sense of security and build solidarity with other classroom members sharing the same native language (Auberbach, 1993; Martin-Jones, 1995). When L1 is used in a moderate and judicious way, teacher's or students' codeswitching to the shared native language would imply tolerance and respect to the other language/s and cultures, thus assume a rapport-building function and help to establish a supportive classroom environment (Crystal, 1987).

Group work is reported to pave the way for a great deal of codeswitching particularly in EFL classes where the learners share the same native language (Brown, 2007). On the other hand, research on codeswitching in group work in the EFL classroom is limited and inconclusive (Amorim, 2012; Chen \& Hird, 2006; Swain \& Lapkin, 2000). Chen and Hird (2006) in their study within a Chinese EFL setting found out that it is inevitable for ELF learners not to codeswitch in their discussions and they usually do so for not knowing the right word, or procedural functions to facilitate smooth running of the group task. In the study of Amorim (2012), codeswitching was similarly used in group work to fulfil various pragmatic functions such as filling in lexical or grammatical gaps in the target language, negotiating meaning and managing the activity and the other participants. According to Amorim (2012), it is natural to encounter codeswitching in student-student interactions within EFL contexts and neither mechanic integration of L1 into the classroom nor banning it is useful, thus the teachers are recommended to be aware of its reasons and functions and act accordingly. According to Swain and Lapkin (2000), codeswitching and L1 use in group work have important cognitive and social functions that support learning such as moving the task along, focusing attention and interpersonal interaction.

Given that codeswitching as a purposeful and a compensatory means is a common component in EFL classrooms consisting of students sharing the same native language and that there is scarcity of research on codeswitching in group work, particularly in EFL settings, there is a need for research on the issue so that stakeholders in ELT, especially those working with English language learners with same native language can make feasible decisions. To deal with the issue of codeswitching realistically and effectively, research should investigate the reasons for codeswitching as is the case in this study, which addresses the following research question:

Why do the EFL students who share the same native language codeswitch in group work? 


\section{Method}

\subsection{Setting}

The research was conducted in the EFL classes within the intensive English programme of a state university in Turkey. There are four English courses given to students in the intensive English programme: Main Course, Reading, Writing, and Listening \& Speaking. The research was carried out in the Main Course, in which English is taught via a series of coursebooks. Main Course is marked with the intensity of the group work activities in the lessons owing to the coursebooks that emphasize collaborative learning. Also it is the course with the highest number of class hours (10 out of 20 hours per week) in the setting.

\subsection{Participants}

The sample consisted of eight groups which included four members each so there were 32 participants in total. They were young adult male and female EFL learners between 18-24 years old with an identical L1, which is Turkish.

\subsection{Data collection procedures}

This study was conducted in the natural settings of two pre-intermediate level EFL classrooms. The data were collected via actual group work observations and their recordings as well as open-ended questionnaires given to the students. The participants were informed about the study, the procedures and confidentiality and voluntarily participated in the research. In order to collect data about group work processes, actual processes in three group work activities performed within the natural setting of the classroom were observed by the researchers and video-recorded. The activities were parts of the units scheduled in the given syllabus. There were three activities applied after the instruction of the grammar subject in the curriculum, which was "quantifiers". The first activity was an ask-and-answer activity in which the students asked the group members questions about their daily life by using question words like "How often", "How many times", "How many", "How much" etc. The aim was practising quantifiers like "a lot of, a few, no, none" etc. In the second activity, the students did the jigsaw reading activity of the unit to be covered. The reading had two parts and the group was divided into A and B. As and Bs were asked to tell what their reading part was about to each other. The subject of the reading was 'Slow Life'. In the third activity, the students were asked to choose statements from among the given statements about slowing down life in a big city and they were asked to write if they agreed or disagreed with those statements with three supporting sentences. The aim of including different tasks was to enhance the process of interaction for the research process in order to collect adequate amount of data as well as see whether the given task types affected the codeswitching behavior. The instructor used mostly English, but in order to clarify the instructions, she sometimes reverted to Turkish. After the class started group work, the instructor walked around and stood beside the groups randomly for short periods, watched them silently and she did not intervene in group work interactions and did not make any warnings when the groups switched to their native language. This was intentionally done to investigate the natural interactional flow of group work tasks. As the instructor said, the dominant language in her classes was normally English and the students would normally be encouraged to speak in L2.

The research lessons were conducted in the school hall bigger than the normal classrooms for a better recording quality. The group work processes were recorded through the recording equipment put in front of each group. During the recording processes, the researchers sat with randomly selected groups in each activity and during group work they kept silent and did not intervene any way not to deteriorate the 
natural flow of communication. Each researcher sat with different groups in each activity and took field notes.

In addition to the classroom observations and recordings, open-ended questions given to the students were also used for data collection. That is, the students who displayed codeswitching behavior were asked to report their possible reasons for codeswitching in an open-ended questionnaire. For this purpose, after the lessons with group work were over, the video recordings of each group were watched by the researchers and each codeswitching statement in each group work interaction was written with the names of the students who uttered them and the Turkish components were bolded in each statement to draw attention. Then a relevant open-ended questionnaire for each student who did codeswitching was prepared. The questionnaire was in the form of a table with two columns. In the first column, the conversational parts where the student switched to L1 were written with highlights on the Turkish part. In the second column, the student was asked to state why s/he thought s/he switched to L1 in the given case. Then each student who did codeswitching in group work was provided with the DVD recording of their group work activity and asked to watch it and write the reason/s s/he suggests for his/her codeswitching in the open-ended questionnaire accordingly.

\subsection{Data analysis}

The data were qualitatively analyzed to determine the causes of codeswitching in group work in the EFL classroom. To find out the reason/s for each codeswitching act, conversation analyses concerning the interactions in group work were performed. As stated by Sert and Seedhouse (2011), through conversational analysis researchers can "document the interactional organisation of second language classrooms and uncover the reflexive relationship between pedagogy and interaction" (p.2). The conversational analyses were conducted at a micro and a macro level. Micro-analyses focused on the single utterances where the students were found to have displayed codeswitching and macro-analyses on the conversational segments leading to the act of codeswitching. Then a thematic analysis was performed. Thematic analysis is "a method for identifying, analysing, and reporting patterns within data" (Braun \& Clarke, 2006, p.6). In thematic analysis, the emerging patterns or themes are defined and categorized by moving back and forth within the data via multiple readings (Creswell, 2013). In this study the repetitive patterns addressing different purposes of codeswitching were also grouped, categorized and named under the given titles. To investigate the reasons stated by students for codeswitching, the student questionnaires with open-ended items were also thematically investigated through iterative readings and in-depth analyses and the given reasons were meticulously refined and categorized with relevant titles.

\section{Results}

Codeswitching in EFL group work was found to serve mainly four purposes namely, i) search for equivalence, ii) meaning clarification, iii) following task procedure, and iv) emotional expression as elaborated below.

\subsection{Search for equivalence}

Most learners were found to use codeswitching to search for the equivalences of the Turkish words with literal or idiomatical meanings. They asked questions like 'Neydi? /What was that?' or 'Ne demek?/ What does (it) mean?' and asked for the help of their friend as exemplified and highlighted below: 


\section{S1: How many hours do you watch TV in a day?}

S2: Errr, I watch TV maybe four or five hours in a week. It isn't good activity I think. If I watch TV, I don't feel so good because TV is boring I think.

S1: But isn't it too much?

S2: But sometimes I watch ... errr ... mmm ... neydi? (what was that?) Sometimes I watch...

S1: News?

S2: Hmm, news. Sometimes I watch news. It is good I think.

For the codeswitching above, S2 stated that he was not able to remember the word "news" at that time. Similarly the students who used codeswitching to search for meaning said that they did not know or remember the word/s in Turkish and asked for the English equivalence/s to others. As the interaction above shows, the student in search of equivalence asked for help and he was helped by his friend as was seen in all the other cases.

There were two reasons found to have caused this form of codeswitching on the basis of the students' reports. These were i) lack of proficiency and ii) finding L1 communication convenient with interlocutors sharing the same native language. The students who referred to the lack of proficiency said they did not have the required competence due to not having sufficient opportunities to speak in L2 inside and outside the classroom. The number of hours spent for speaking English in class and the time devoted to one-to-one interactions within those in-class practices were deemed to be limited. Also, most students mentioned not being able to use English outside the classroom and the students who stated that they used English outside the classroom mentioned only the internet communication. Some students even said that as a result of this lack of proficiency, they had a habit of translation in speaking. These students perceived translation as a natural communication strategy and added that while communicating in English what they do is making word-for-word translations of the Turkish sentences into English in their minds. Those students reported that they could not exactly translate the utterances in their group work interactions so they switched to Turkish.

Another reason for codeswitching in equivalence search was that since the students shared the same native language, they said that they found using Turkish phrases like "Neydi? /What was that?" or "Ne demek? What does (it) mean?" to ask for the correct equivalence more natural than employing the English counterparts. They described using English in those cases as artificial and unnecessary. Hence, the interlocutors' common characteristic, which is speaking the same native language, has been an effective factor in their opting for the codeswitching strategy.

\subsection{Meaning clarification}

In some situations the students used codeswitching as a strategy to clarify in Turkish what they meant by their English utterances. For instance they uttered the Turkish equivalence of a word, phrase or sentence immediately after the English expression as seen in the following excerpt:

S3: Can you give me examples about slow foods?

S4: Slow foods?

S3: I think some traditional food.

S4: Traditional?

S3: Traditional? Geleneksel.

S4: Oh I know traditionals mean. < laughs >

S3, who commented on his codeswitching, said that he thought he was not understood at that time and in order to clarify the meaning he switched to Turkish. Having the concern about not being understood was given as the common reason by the students for this aspect of code-switching. For 
instance one student said that if he does not understand something and if the other person insists on explaining the expressions by using English words, the meaning becomes vague and may be misunderstood. Thus codeswitching was used as a strategy to achieve mutual intelligibility as the interlocutors spoke the same native language.

Meaning clarification sometimes had the form of asking for confirmation and the participants were observed to use "miydı?/miydi? (Is it?)" for this confirmation request. In those situations one of the students always helped the other by confirming or suggesting an alternative as it is the case in the following interaction:

S5: I usually eat fast food twice in a week. I don't like but I am. 〈pause> Obligate miydi? (Is it obligate?) <laughs>

S6: I must.

S5: Hmm, yes, I must. I haven't another choice.

S6: Because?

S5: I don't have another choice, because I stay in a dormitory.

Codeswitching as seen in the above excerpt acts as a resource to form fluency in the interaction as it just comes after a pause and draws the interlocutors to negotiate meaning through scaffolding. This is verified by the student report in the way that when meaning is clarified, communication is facilitated. Thus another reason underlying meaning clarification is achieving fluency in the flow of interaction.

The attempts to switch to Turkish for meaning clarification were also made in the form of using the Turkish word 'yani (that is / in other words)'. The students who used it said that they used the word to make their interactions fluent and also save time for forming the subsequent sentences. Thus meaning clarification through CS was achieved via not only translations or confirmation requests but also using L1 connectors that signal elaboration and accordingly clarification.

\subsection{Following task procedure}

The students were also found to have performed codeswitching in an attempt to follow the given group task procedure effectively. In their task steps, most of the students were observed to have been motivated and serious about accomplishing the task goals and codeswitching was seen to act as a means for the participants to carry out the task as required. L1 was found to have the function of a metalanguage in the task fulfilment process with the following sub-functions:

- Asking questions about task steps

- Clarification of the task steps

- Giving directions

All these functions of codeswitching about the task procedure can be seen in the following excerpt as a whole as highlighted by relevant items:

S7: <pointing at the camera> Çevir onu. (Turn it.) - (giving a direction)

S8: OK, last person. Kim soruyor? (Who is asking?) - (asking a question about the task procedure)

S9: Ben soracağım. (I will ask.) - (attempt for task clarification) - I wanna ask an important question. I think in Turkey it is important question. How many novels do you read a month?

The reports of the students showed that most students found it natural to have switched to L1 to apply the task procedure effectively. The students said that those kinds of codeswitching attempts to follow the procedure were unconscious acts deriving from their desires to get the task done in the best way. 
According to the conversation analyses, two factors might also have driven the students to switch to Turkish. One of them was the possible effects of teacher talk while giving instructions. In one of the tasks, possibly in order to clarify the procedure, the instructor also codeswitched to give instructions as seen in the following excerpt:

You are going to write if you are for or against it. OK? $\ddot{U} c ̧$ tane seçiyoruz. For musunuz? Against mi? Arkada yazlyor bakın. (You are going to choose three aspects. Are you for or against it? It is written at the back. Look.) I am for or against, why. Üç tane aspect hakkında. (About three aspects.) Would you please write them with your partner? You are going to give it to me. Three aspects.

Thus the teacher's codeswitching in clarifying task procedure might have been taken as a norm since the students following this instruction were also found to have applied it in their procedural clarifications.

Moreover, the task type as involving spontaneous speech or production of an outcome (a piece of writing in our case) also seemed to have led to codeswitching in group work. The students were seen to have made much more use of codeswitching in the latter. For instance in one of the groups, the students directly switched to L1 after they received the procedural instructions from the teacher and clung to that interaction in L1 extensively until the end of the task. Most students in this case reported that using L1 saved time and they thought it was not necessary to speak in L2 in the production process since the important thing was the written product. Time pressure was also mentioned in some other cases. The students complained about the limited time they had in accomplishing the tasks and said that they employed codeswitching for this reason.

\subsection{Emotional expression}

According to the findings, the participants switched codes to express their emotions while giving sudden emotional reactions or to make humour or to address their friends through intimate forms. For the first category it was found that codeswitching occurred in cases with sudden arousal of emotions, for instance surprise as in "Aaa, doğru ya! (Oooh, it's true!)", anxiety as in "Telefon çallyor, kapat çabuk çabuuuk!/ (The phone is ringing, turn it off, be quick! Quiiick!)” or sadness or anger "Of! Hep unutuyorum! (Oh! I always forget this!)". The students who gave such reactions stated that they did so without thinking since they were not able to take control of these sudden reactions and also some said that as they feel closest to their native language, Turkish, it would be the best way to express them.

The participants were also seen to switch to their L1 to make humour as seen in the following excerpt:

S12: How much?

S13: 60 dollars.

S12: <laughs> 60 dollars? Ay, çok fazla, 50 yapalım şunu. (Oh, it's too much, Let's make it 50.)

S14: <in a humourous tone> Evet, ciddiyet lütfen! (Yes, be serious please!)

Most of the participants who switched to L1 to make humour said it felt natural to do so in their native language. Also some of them stated that their English is not proficient enough to make humour, hence they do so in their L1. In some humour cases, some common cultural expressions in Turkish like "Kolay gelsin / May it be easy" or "Hayirli isler / Have a nice working day" were told in Turkish and their utterances caused an impact of humour in the interactions. The students who told such expressions said that they did not know or could not find their equivalences in English and they opted for Turkish also because they would make sense only in Turkish since they are cultural expressions and also because their Turkish partners would understand them. Some also mentioned that even if they were able to make 
jokes in English, they would not have the effect of jokes made in Turkish and feel artificial and unintelligible since they believe humour can be made in the most effective way only through native language.

The third category of codeswitching to express emotions was seen in the use of address terms. When some students addressed to each other, they sometimes used Turkish forms of address indicating intimacy like 'hocam' or 'abi', which can be translated as "buddy". It was found that the students' codeswitching in this case had the purpose of rapport building and this might have occurred in group work activities since group work has the potential to allow for relatively more intimate forms of interactions compared to whole class instruction or teacher-student interaction due to closer relations. Also as the ages and the statuses were almost equal in our case, codeswitching probably built a firmer solidarity, as revealed through high number of expressions reflecting rapport.

\section{Discussion}

The findings on the use of L1 in group work have revealed that the students with the same language background in an EFL class used codeswitching in their group work activities for certain purposes. In this study the functions of L1 were found to have been concerned with search for equivalence, meaning clarification, following task procedure and emotional expression. The students asked for help to search for the equivalences of words via codeswitching and the replies they got helped them to go on with their communication. They also switched codes to clarify what they meant to help their partners in cases where they felt that they could not be understood or could have been misunderstood and this was another attempt to achieve mutual intelligibility in their communication. The L2 interaction, although intervened by L1 utterances at some points, went on smoothly on the path of fulfilling the intended communication purposes. Codeswitching then seemed to have worked as an effective tool in accomplishing certain communicative purposes in L2 interaction with the interlocutors that share the same mother tongue. Not to mention the fact that codeswitching also formed a positive atmosphere in the groups with the potential to increase motivation and reduce stress by its time-saving and rapport building functions. Codeswitching was also seen to be a builder of solidarity among the learners since it was employed to make humour and address the partners in the shared culture and thus to support the 'we' code in the very nature of EFL classrooms where often students with the same native language study.

On the other hand, it was also found that the task type may well affect the quantity of codeswitching in group work. In the spontaneous speaking tasks, there was limited use of codeswitching and it was seen to facilitate communication as a compensatory tool and a means to clarify meaning. However, the students' codeswitching and accordingly L1 use highly increased in the productive task, which targeted at the production of a written outcome by the group. In this joint form of action which required a concrete outcome, the students were seen to have used L1 extensively so as to build accurate and meaningful sentences in writing. This can be explained by the on-record and off-record modes originally defined by Hancock (1997) for group work. Hancock (1997, p.217), defined the former as the one concerning the negotiation between learners within group work and the latter as the one performed to be overheard by a referee (a potential L2 audience). The predominant language was found to be the native language in the off-record level and L2 in the on-record level. Thus it is stated that it is significant not to presume all L1 use as "sin" and all L2 use as "good deed" in group work. Learners may revert to L1 in the offrecord mode due to their concerns to present an effective performance in the on-record mode. Hence, codeswitching has its own purposes in group work and teachers dealing with group work must take language choice behaviour in different modes into account (Chen \& Hird, 2006). In this study, to present an effective outcome to the teacher and the whole class in the on-record mode, the learners displayed an 
off-record mode by switching to L1 and using it in high amounts. This implies the fact that banning L1 from the L2 class may not be an efficient practice particularly in classes where the same native language is shared since the use of L1 may enable the students to share their ideas and suggestions clearly and productively and drive them to make efficient preparations for spoken or written outcomes to be displayed in public performance. Thus in production tasks in group work, the students may be given the initiative to decide upon their own procedures and set free in their choice of language in the preparation stage. Another choice is an explicit directive to use L2 according to Hancock (1997, p.229), since the use of L1 in the off-record discourse may be "largely a matter of default" and without an explicit warning, it would not occur to the participants to use L2.

The research has shown that codeswitching in group work can be a communicative and a productive resource to help build effective outcomes. This finding is in agreement with the findings of the studies about group work in EFL classes where codeswitching has also contributed to negotiation of meaning as well as task management (Amorim, 2012; Chen \& Hird, 2006; Swain \& Lapkin, 2000). This study also highlights the fact that codeswitching can act as a means of diagnosing the deficits of the students about structural, pragmatic and strategic competence as well as a catalyst to take the required measures to cover these gaps. The students mentioned that their lack of proficiency was a reason for their codeswitching, which signals the significance of some measures to be taken in the English classroom. Even if the teacher may allow the students to codeswitch in their communication for search of equivalence or clarification of meanings in group work tasks, s/he must make sure that before the tasks are instructed, the students are provided with the necessary vocabulary and grammar knowledge about the task and the students have practised the necessary communication strategies if necessary. Thus the students should first be encouraged to make use of all the possible L2 means (e.g. vocabulary, grammar, communication strategies) in their repertoire to express themselves and the use of L1 can be allowed in the English classroom when communication in L2 is deteriorated in the real sense due to lack of fluency.

The teacher's role and institutional policies cannot be ignored at this point. There should be sensible decisions taken by teachers and administrators about codeswitching and the use of L1 in the classroom with specifications about where to use L1 and what to allow and what not to allow in terms of L1 use taking all the context- and situation-specific factors into consideration. L2 classroom should be a place facilitating effective communication and efficient improvement of language skills in L2, thus there should be a balance in L2 and L1 use in the EFL classroom. Also teachers should pay attention to use codeswitching only for specific purposes when necessary (e.g. clarifying instructions or giving the L1 equivalences of complex vocabulary) as the students may easily switch to L1 if the teacher uses it as seen in one situation in this study. Thus it is necessary that L2 have a governing role in classroom communication and L1 be used in a limited way for defined purposes. The stakeholders can also make use of the results of codeswitching studies on the issue and investigate the matter in their own settings if need be. Only with consistent, context-sensitive and research-based decisions can they be successful in managing the pedagogical aspects of codeswitching.

Finally, it is a fact that using codeswitching as a communication strategy would work with interlocutors with identical mother tongues, but it may not help participants achieve their communication purposes in real life if L2 is to be used as a global lingua franca with speakers having different language backgrounds. Thus codeswitching in the EFL classroom can act as a multifunctional asset, but the use of L1 should be at a limited level and English must still be the dominant language in the classroom since in an EFL setting, classroom is often the only opportunity to improve one's English and practise communication. Moderate use of L1 has the potential to bring about a multifaceted perspective to the language teaching context since both the native language and L2 would then be acknowledged with their own purposes. Defining the causes of codeswitching in the EFL class, particularly group work would lead language teachers, administrators, material and curriculum 
developers and ELT researchers to create context-sensitive and student-friendly English teaching and learning environments.

\section{Conclusion}

This study concludes that codeswitching assumes the functions of search for equivalence, meaning clarification, following task procedure and emotional expression. The qualitative analyses of the data also show that L2 learners of English provided a number of reasons for practicing codeswitching in group work, namely lack of proficiency, finding L1 communication more convenient with interlocutors sharing the same native language, achieving mutual intelligibility and preventing communication breakdowns, saving time and building solidarity. Some other factors that possibly influenced the extent of codeswitching in group work were the type of the task, the students' being in an on-record or offrecord mode and the extent of the instructor's use of L1 in the classroom. Knowing the reasons that underlie codeswitching is highly important for stakeholders in EFL classrooms so that they can make viable decisions on the extent of codeswitching in the classroom and the ways of using it as an effective pedagogical means.

Accordingly, this current study proposes that restricted use of codeswitching in the EFL classroom environment may help L2 learners benefit from the advantages of we-code in group work. On the other hand, more research with different pair and group work activities is needed to define the facilitative roles and pedagogical benefits of codeswitching in EFL contexts.

\section{Ethics Committee Approval}

The author(s) confirm(s) that the study does not need ethics committee approval according to the research integrity rules in their country (Date of Confirmation: May 29, 2020).

\section{References}

Amorim, R. (2012). Code switching in student-student interaction; functions and reasons! Revista de Estudos Linguísticos da Univerdade do Porto, 7, 177-195.

Atkinson, D. (1993). Teaching monolingual classes. London: Longman.

Auberbach, E. R. (1993). Re-examining English only in the ESL classroom. TESOL Quarterly, 27(1), 9-32.

Bateman, B. E. (2008). Student teachers' attitudes and beliefs about using the target language in the classroom. Foreign Language Annals, 41(1), 11-28.

Bhatt, R. M. (1997). Codeswitching, constraints, and optimal grammars. Lingua, 102(4), 223-251.

Braun, V. \& Clarke, V. (2006). Using thematic analysis in psychology. Qualitative Research in Psychology,3,77-101.

Brown, H.D. (2007). Teaching by principles: An interactive approach to language pedagogy $\left(3^{\text {rd }}\right.$ edition). New York: Pearson/Longman.

Burenhult, N. \& Flyman-Mattsson, A. (1999). Codeswitching in second language teaching of French. Lund University Department of Linguistics Working Papers, 47, 59-72. 
Chambers, F. (1991). Promoting use of the target language in the classroom. Language Learning Journal, 4, 27-31.

Chaudron, C. (1988). Second language classroom: Research on teaching and learning. Cambridge: Cambridge University Press.

Chen, R. \& Hird, B. (2006). Codeswitching in EFL group work in China. Language, Culture and Curriculum, 19(2), 208-219.

Cook, V. (2016). Second language learning and language teaching $\left(5^{\text {th }}\right.$ ed.). New York, Routledge.

Creswell, J. (2013). Qualitative inquiry and research design: Choosing among five approaches. Thousand Oaks, California: Sage.

Crystal, D. (1987). The Cambridge encyclopedia of language. Cambridge: Cambridge University Press.

Duff, P. A. \& Polio, C. G. (1990). How much foreign language is there in the foreign language classroom? Modern Language Journal, 74, 154-166.

Ellis, R. (1984). Classroom second language development. Pergamon: Oxford.

Eldridge, J., (1996). Codeswitching in a Turkish secondary school. ELT Journal, 50(4), 303-311.

Galloway N. \& Rose H. (2015). Introducing Global Englishes. London: Routledge.

Galloway, N. \& Rose, H. (2018). Incorporating Global Englishes into the English classroom. ELT Journal, 72(1), 3-14.

Greggio, S. \& Gil, G. (2007). Teacher's and learners' use of code switching in the English as a foreign language classroom: a qualitative study. Linguagem \& Ensino, 10(2), 371-393.

Hancock, M. (1997). Behind classroom code switching: Layering and language choice in L2 learner interaction. TESOL Quarterly, 31(2), 217-235.

Harmer, J. (1983). The practice of English language teaching. London: Longman.

Jingxia, L. (2010). Teachers' code switching to the L1 in EFL classroom. The Open Applied Linguistics Journal, 3, 10-23.

Kemaloglu-Er \& Bayyurt, Y. (2018). ELF-aware pre-service teacher education: Teaching practices and reflections from Turkey. In L. Cavalheiro (Ed.), Preparing English language teachers for today's globalized world (47-63). Lisbon: Humus \& University of Lisbon Centre for English Studies.

Kemaloglu-Er \& Bayyurt, Y. (2019a). ELF-awareness in teaching and teacher education: Explicit and implicit ways of integrating ELF into the English language classroom. In N. C. Sifakis \& N. Tsantila (Eds.), English as a Lingua Franca for EFL contexts (147-163). Bristol, UK: Multilingual Matters.

Kemaloglu-Er \& Bayyurt, Y. (2019b). Project-based and ELF-aware pre-service teacher education in Turkey: Sample cases of discovery, creativity, interaction and multicultural diversity. In A. GrasVelazquez (Ed.), Project-based learning in second language acquisition: Building communities of practice in higher education (82-97). London: Routledge.

Kumaravadivelu, B. (2003a). Beyond methods: Macrostrategies for language teaching. New Haven, CT: Yale University Press.

Kumaravadivelu, B. (2003b). Forum: critical language pedagogy: A postmethod perspective on English language teaching. World Englishes, 22(4), 539-550.

Lally, C. G. (2000). First language influences in second language composition: The effect of pre-writing. Foreign Language Annals, 33(4), 428-432. 
Larsen-Freeman, D. (2000). Techniques and principles in language teaching (4 $4^{\text {th }}$ ed.). Oxford: Oxford University Press.

Levine, G.S. (2003). Students and instructors beliefs and attitudes about target language use, first language use, and anxiety: report of questionnaire study. Modern Language Journal, 87, 343-364.

Lin, A. M. Y. (2008). Codeswitching in the classroom: Research paradigms and approaches. In K. A. King, and N. H. Hornberger (Eds.), Encyclopedia of language and education - Volume 10: Research methods in language and education (pp. 273-286). New York: Springer Science.

Macaro, E. (2009). Teacher use of code switching in the second language classroom: Exploring “optimal” use. In M. Turnbull \& J. Dailey-O'Cain (Eds.), First language use in second and foreign language learning (pp. 35-49). Cambridge: Cambridge University Press.

Macaro, E. \& Lee, J. H. (2013). Teacher language background, codeswitching, and English-only instruction: Does age make a difference to learners' attitudes? TESOL Quarterly, 47(4), 717-742.

Maguddayao, R. \& Rosario, O. (2019). Code switching of English language teachers and students in an ESL classroom. Asian EFL Journal, 21(3), 102-122.

Martin, P. W. (1999). Close encounters of a bilingual kind: interactional practices in the primary classroom in Brunei. International Journal of Educational Development, 19(2), 127-140.

Martin-Jones, M. (1995). Codeswitching in the classroom: Two decades of research. In L. Milroy \& P. Muysken (Eds.), One speaker, two languages: Cross-disciplinary perspectives on codeswitching (pp. 90-111). Cambridge: Cambridge University Press.

Matila, R. (2009). Decoding the switch: The functions of code switching in the classroom. Education Quarterly - U.P. College of Education, 67(1), 44-61.

Miles, R. (2004). Evaluating the use of L1 in the English language classroom. Birmingham: University of Birmingham.

Prucha, J. (1983). Using language: A sociofunctional approach. In B. Bin (Ed.). The sociogenesis of language and human conduct. New York: Plenum Press.

Richards, J. C. \& Rodgers, T. S. (2001). Approaches and methods in language teaching (2 ${ }^{\text {nd }}$ edition). Cambridge: Cambridge University Press.

Qing, X. (2010). To switch or not to switch: Examine the codeswitching practices of teachers of nonEnglish majors. Canadian Social Science, 6(4), 109-113.

Sampson, A. (2012). Learner codeswitching versus English only. ELT Journal, 66(3), 293-303.

Sert, O. (2005). The functions of codeswitching in ELT classrooms. The Internet TESL Journal, 11(8), Retrieved on May 9, 2020, from http://iteslj.org/Articles/Sert-CodeSwitching.html

Sert, O. \& Seedhouse, P. (2011). Introduction: Conversation analysis in applied linguistics. NovitasROYAL (Research on Youth and Language), 5(1), 1-14.

Stern, H.H. (1992). Issues and options in language teaching. Oxford: Oxford University Press.

Sutherland, S. (2012). Native and non-native English teachers in the classroom: A reexamination. Arab World English Journal, 3(4), 58-71.

Swain, M. \& Lapkin, S. (2000). Task-based second language learning: The uses of the first language. Language Teaching Research, 4(3), 251-274. 
Turnbull, M. (2001). There is a role for the L1 in second and foreign language teaching. Canadian Modern Language Review, 57(4), 531-540.

Üstünel, E. \& Seedhouse, P. (2005). Why that, in that language, right now? Codeswitching and pedagogical focus. International Journal of Applied Linguistics 15(3), 302-324.

Vaezi, S. \& M. Mirzaei (2007). The effect of using translation from L1 to L2 as a teaching technique on the improvement of EFL learners' linguistic accuracy - focus on form. Humanising Language Teaching, 9(5), Retrieved 10 May, 2020, from http://old.hltmag.co.uk/sep07/mart03.htm

Weschler, R. (1997). Uses of Japanese in the English Classroom: Introducing the Functional-Translation Method. Kyoritsu Women's University Department of International Studies Journal, 12, 87-110.

Wong-Fillmore, L. (1985). When does teacher talk work as input? In S. M. Gass, C. G. Madden (Eds.), Input in second language acquisition (pp. 17-51). Newbury: Rawley, MA.

Yang, M. (2004). A study of codeswitching in Chinese EFL classrooms: A pragmatic approach. SinoUS English Teaching, 1(10), 43-49.

Zabrodskaja, A. (2007). Russian-Estonian codeswitching in the university. Arizona Working Papers in SLA \& Teaching, 14, 123-139.

Zhu, H. (2008). Duelling languages, duelling values: Codeswitching in bilingual intergenerational conflict talk in diasporic families. Journal of Pragmatics, 40(10), 1799-1816.

\title{
Yabancı dil olarak İngilizce sınıflarındaki grup çalışmalarında
}

\author{
düzenek değiştirme
}

\section{$\ddot{\mathbf{O} z}$}

Düzenek değiştirmenin yabancı dil olarak İngilizce öğrenilen, özellikle aynı anadili paylaşan öğrenicilerin olduğu sınıflarda yaygın bir özellik olduğu bildirilmiştir. Ancak yabancı dil olarak İngilizce öğrenilen bağlamlardaki grup çalışmalarında düzenek değiştirmeyle ilgili çok az çalışma vardır. Bu çalışma yabancı dil olarak İngilizce öğrenilen ortamlardaki aynı ana dili paylaşan öğreniciler arasındaki grup çalışması etkileşimlerinde düzenek değiştirmenin uygulanma nedenlerini araştırmayı amaçlamaktadır. Veriler yabancı dil olarak İngilizce öğrenilen bir ortamdaki grup çalışması süreçlerinin gözlemleri ve öğrencilere verilen açık uçlu anketler yoluyla toplanmış ve tematik olarak analiz edilmiştir. Sonuçlara göre, grup çalışmalarında düzenek değiştirme temelde dört amaca hizmet etmektedir: i) eşdeğerlik arayışı, ii) anlamın netleştirilmesi, iii) görev prosedürünü takip etme, iv) duygusal ifade. Görev türünün spontan konuşma görevi ya da ürün üretme görevi olup olmaması ve öğrencilerin kayıt modunda olma ve kayıt modunda olmama durumu da düzenek değiştirmenin oranını etkilemiştir. Bir diğer bulguya göre ise öğretim görevlisinin sınıfta anadil kullanımı öğrencileri düzenek değiştirmeye sevkedebilmektedir. Öğrenciler İngilizceden ana dillerine, özellikle yeterlik eksikliğinden ve ana dil iletişimini kaygılarını ve duygularını ifade etmede kullanışlı bir yol bulmalarından dolayı geçiş yaptıklarını belirtmişlerdir. Düzenek değiştirmenin dayanışmayı inşa eden bir unsur ve görev amaçlarını ve etkileşimsel akıcıllğı başarmada bir araç olduğu bulunmuştur. Bu bulgular, düzenek değiştirmenin yabancı dil olarak İngilizce sınıflarındaki grup çalışmalarında pedagojik olarak yararlı amaçlara hizmet edebileceğine işaret etmektedir.

Anahtar sözcükler: düzenek değiştirme; grup çalışmalarında düzenek değiştirme; yabancı dil olarak İngilizce sınıflarında düzenek değiştirme; düzenek değisştirmenin nedenleri 


\section{AUTHOR BIODATA}

Elif Kemaloglu-Er is an assistant professor in the Department of Translation and Interpreting at Adana Alparslan Türkeş Science and Technology University. Prior to this position, she worked as an instructor of English for Academic and Specific Purposes at Bogazici University School of Foreign Languages. She earned her PhD degree in English Language Education at Bogazici University. Her research interests include English language teaching, pre-service and in-service language teacher education, ELF \& World Englishes, and L1 use and codeswitching in EFL contexts.

Hatice Özata is an assistant professor in the Department of Foreign Language Education at Giresun University. Prior to this position, she worked as an instructor of English in the School of Foreign Languages at Y1ldiz Technical University. She got her $\mathrm{PhD}$ degree in English Language Education at Bogazici University She is particularly interested in literacy acquisition in first and second language, bilingualism, language transfer, cognitive and linguistic processes in language acquisition, reading difficulties, English-medium instruction, code-switching and teaching English as a foreign language. 